\title{
DIFFERENT EFFECTS ON EARNINGS MANAGEMENT OF FOUR KINDS OF EXECUTIVE POWER: AN EMPIRICAL STUDY IN CHINA
}

\author{
Wang Lingyun \\ Nanjing University of Aeronautics and Astronautics, Economics and Management College \\ Wang Julan \\ SHU-UTS SILC Business School, Shanghai University, P.R.China \\ Zhang Long \\ Nanjing University of Aeronautics and Astronautics, Economics and Management College, \\ P.R.China \\ Hu Enhua* \\ Nanjing University of Aeronautics and Astronautics, Economics and Management College, \\ P.R.China
}

\begin{abstract}
This paper takes an empirical study to examine and evaluate different effects on earnings management of four kinds of Executive power by taking the samples of 216 listed enterprises with equity incentive plan. Executive power was decomposed into four types: organization structure power, expert power, prestige power and ownership power. This paper finds that Executive structure power, ownership power and expert power have positive effects on earnings management, while prestige power has negative effects on earnings management. Because of the differences in the direction of effects from different Executive powers on earnings management, these effects offset each other, leading to unstable effects on earnings management of overall executive power both in direction and in degree.
\end{abstract}

Key words: Equity incentive, Executive power, earnings management

JEL code: G4, M5

\section{Introduction}

Earnings management is a qualified behavior in the range of Generally Accepted Accounting Principles by using the accounting methods and un-accounting methods and treating the accounting information basis by the management achievements in order to obtain value-maximum of private companies. Companies have the demand of earnings management due to the pressure of the capital market. For example, Yili company calculated and extracted stock incentive cost in 2007, which led to book loss and price limit (lv \& Gong, 2009), TYDIC company increased high-tech development costs in order to reduce book profit (Li \& $\mathrm{Li}, 2014)$. However, changing the book earnings is not the sole cause of earnings management, at least not the sole determinant of earnings management. Many scholars have noticed that some factors associated with the earnings management are essential. Bergstresser and 
Philippon(2006) believed that the higher level at which the Executives get prompted, the greater possibility that they can take advantage of information asymmetry of the investors to conduct earnings management, so as to make the price of company stock and option higher. Xiao et al. (2009) discovered that the equity incentive plan before the announcement of the first three quarters, Executives will calculate downward earnings management, but after the announcement, they will calculate to the earnings management, so as to realize the maximization of equity incentive income. Kedia and Philippon (2009) found that the probability of positive correlation between the number of managerial equity incentives awarded to mangers and companies' earnings misstatement after studying 539 companies' financial information, which shows that the greater number of equity incentive Executives have, the higher the company's earnings management will be. Ding, Liu and Liu (2012) believe that in China, the capital market still being immature, there are many shortcomings and deficiencies in the implementation of equity incentive in the listing Corporations, increasing the Executive of the possibility of earnings management (Bebchuk \& Fried, 2003). Achilles, Blaskovich and Pitre (2013) found that, when the incentive compensation links performance, Executives will adjust the earnings of the company based on earnings forecasts, which shows that the performance of the incentive will be linked to inducing earnings management.

However, earnings management is a risky behavior. What is the situation in which Executives dare to manage earnings management? Some studies have explored the role of the authority of the Executive. Under the assumption of economic man, when the level of equity incentive is high, if the Executive's power is large enough, they may use its power to influence the board of directors to make a decision of their own interests (Wang \& Wang, 2007). Quan and Wu (2010) found that the greater the power of state-owned enterprise Executives have, the stronger the motivation of Executives to obtain incentive compensation will be (Zha \& Luo, 2013). In the perspective of risk aversion, if the power of the Executive is large enough, it can improve the compensation outside of the stock option, and it is not necessary to improve the return of equity incentive through earnings management, because of the risk of it (Zhang \& Yang, 2012). If Executives can use their power to make a significant increase in cash compensation, the incentive to adjust the accounting book by earnings management and the motivation to get incentive compensation will be weakened (Schneidr, 2013), or influence the remuneration decision-making through the power of Executives, weakening its higher pay through earnings management(Wang, 2011).

In reality, whether the Executive's decision is based on the rule of "economic man" to obtain high return on equity through earnings management incentives, or based on risk aversion seeking for a higher fixed salary, may not be an either or thing. As a complex agent, the influence of the Executive on the enterprise is not from a single aspect. Finkelstein (1992) proposed that the power of the Executive is derived from the organization structure, the expert, the prestige and the ownership, which are in list named as organization structure power, expert power, prestige power and ownership power. The different managerial power may have different influences on the earnings management (Chung \& Pruitt, 1996). Firstly, this paper analyzes the influences of the four rights of the Executive on earnings management and 
the direction of its influences; the paper also tests the influence mechanism of different Executive powers affecting the earning management by the data of China listed companies with equity incentive plan; finally, it put forward the related proposal for listed companies to take measures to configure organization structure power, expert power, prestige, power and ownership right power to reduce the earnings management behavior of enterprises.

\section{Literature research and theoretical hypothesis}

\subsection{The effect of Executive organization structure power on earnings management}

The power of organization structure is the power which the Executives are given in the company. The greater the power of organization structure is, the greater the influence will be, and it will be easier for them to manage toward their own advantage. When Executives carry out the equity incentive, they have stronger motivation to get more equity incentive returns through earnings management based on self-interest tendency. In listing Corporations, the influence will be improved if the Executive also serves as chairman of the board of directors (Bantel \& Jackson, 1989), which makes it easier for Executives to develop more in line with their own pay system (Wang, Guan \& Ma, 2003). Bebchuk et al. (2009) found that when the chairman and the Executive are combined together, the control power of CEO will be greater, and the earnings management control is more apparent.

Hypothesis 1: The greater the Executive organization structure power, the bigger the earnings management.

\subsection{The effect of Executive Expert power on earnings management}

Expert power refers to the power of the Executive to use the existing experience and ability to effectively manage the company's power. If the Executive's education level is higher, the ability to understand the company's system and program is greater (Harhoff, 1999). If Executive's tenure is longer, his industry experience is richer, and the reliability of business decisions and power of experts are greater (Fama, 1980). Expert power makes it better to judge the risk of the business, to reduce the risk of earnings management, and to stimulate the motivation of earning high income through earnings management. Zhao and Luo (2013) proposed that if Executives have higher education level and are competent, then their expert power is greater, which makes the Executive easier to make decisions for their personal benefits (Crystal, 1991).

Hypothesis 2: The greater expert power, the bigger earnings management.

\subsection{The effect of Executive prestige power on earnings management}

Prestige power refers to the Executive of good reputation that can get more social trust and support, which improve the companies' social impacts. Good reputation make the Executive not to do earnings management in two aspects: one is that people with good reputation have 
fewer motives to do something looking bad; the other one is that Executives will reduce the motivation of earnings management in order to maintain their social reputation. If the Executive makes a loss to the interest of shareholders, government or other public, once being revealed, his reputation will be damaged, thereby affecting the market returns and the public's recognition of the Executive. The market value of the Executives depend on the recognition of the Executive, so the Executive have the power to establish and maintain the long-term reputation, and then reduce the incentive to make the decision of the loss of the company's earnings(Huang \& Li,2001). In addition, a lot of company shareholders believe that giving the CEO high reputation and reward is a smart investment in management (Li \& Shen, 2013). In addition to the economic incentives, the image of Executive, the value of corporate spirit and culture are also an important manifestation of the spirit of the management (Hambrick \& Finkelstein, 1987). Take Wang Shi and Ma Yun as examples, the Chinese famous enterpriser, for the spirit of Vanke and Alibaba, they will reduce their earnings management by manipulating earnings management to seek higher personal motivation. In addition, in recent years, Medias often report the compensation of Executives of securities market (Gomez-Mejia Larraza-Kintana \& Makri, 2003) and some illegal behaviors that make Executives take into account of the prestige when facing earnings management.

Hypothesis 3: The greater Executive prestige power, the smaller earnings management.

\section{4 effect of Executive power of ownership on earnings management}

The power of ownership is the influence of the Executives on the ownership of the company. If Executives are the major shareholder of the company, the company's sense of belonging is stronger, the Executive's goal is more consistent with the growth target of the company, and the motivation of earnings management is weaker. Compared to the external professional Executives, Executives have ownership and Executive rights, so they are eager to improve the practical value of the enterprise (Gu, Qin \& Ouyang, 2008). In addition, equity is a tool for large shareholders to motivate Executives or small shareholders, and they need to be motivated to create value for the enterprise, thus tending to prevent the enterprise's earnings management behavior.

Hypothesis 4: The greater Executive power of ownership, the smaller earnings management.

\section{Research methods}

\subsection{Sample selection and data sources}

This paper selected companies with equity incentive plan listed in Shanghai Stock Exchange and Shenzhen Stock Exchange before Dec. 31, 2012, as research subjects. The data of these samples are from January 1, 2012 to December 31, 2015. Because there are many motivations of company's earnings management, the paper deletes the interference of the capital market motivation, the supervision motivation and other motives to earnings management. The date 
of the paper is from Shenzhen and CCER China Economic and financial database (www.ccerdata.cn) and the website of listed companies' annual report, and equity incentive related announcement, the shareholders' meeting notice etc. Altogether there are 280 companies implemented equity incentive until Dec. 31, 2012. At the same time, considering the effectiveness of the samples, following companies are excluded: (1) the financial insurance and other controlled companies because these companies' equity incentive results are difficult to truly reflect the impact of the power of Executive; (2) ST, PT companies and loss companies samples. ST and PT companies have a strong incentive to make earnings management by modifying their accounting, and these companies usually have operational problems; (3) 2012 newly- listed companies because they lack the financial data of last year to calculate accruals; (4) Executives in listed companies who do not receive salary from their companies; (5) listed companies which miss some financial data, company governance data and returns. Finally, from the implementation of equity incentives in the 280 listing corporation, the finalized overall study sample is 216 .

\subsection{Variables and measurement}

\subsubsection{Dependent variables and its measurement}

The dependent variable of this paper is earnings management. Accrual method is often used to analyze it in empirical research, that is, to find out the trace of earnings management from the company's accrual profit. First, the accrual profit should be divided into the manipulation of accruals and non-manipulation of accruals that is based on the extent of the profit table, cash flow statement, and balance sheet. Non manipulation of the profits is generally in accordance with the current accounting standards for the results of the mandatory, belonging to the difficult parts to be manipulated. The control of the remaining part of the profit can be estimated by the change of accounting earnings, expenses, capital, asset impairment provision and other ways to control. Cross-sectional Jones model is used to calculate the profit. The theoretical basis of this model is that the non-discretionary accruals are affected by the non-operating income which is subject to fixed assets and operating income. First, we calculate the profit and non-discretionary accruals, and finally come to the controllable accrued profit. Using this model to calculate the discretionary accrual profit can solve the problem of insufficient time span of the original model, and it is the most effective and common method for measuring the discretionary accrual profit(Li, Dong \& Lian, 2011). Concrete steps are as follows:

(1) Calculate total profit

$$
T A_{i, t}=I_{i, t}-C F O_{i, t}
$$

Among them, $T A_{i, t}$ said that the total amount of $\mathrm{i}$ company in i phase; $I_{i, t}$ said the net profit

of $\mathrm{i}$ company in t phase; $\mathrm{CFO}_{i, t}$ said the company's cash flow generated by $\mathrm{i}$.

(2) Estimate the parameters of the model.

$$
T A_{i, t} / A_{i, t-1}=\alpha_{1}\left(1 / A_{i, t-1}\right)+\alpha_{2}\left(\Delta R E V_{i, t} / A_{i, t-1}\right)+\alpha_{3}\left(P P E_{i, t} / A_{i, t-1}\right)+\xi_{i, t}
$$


Among them, $A_{i, t-1}$ is the total assets of $\mathrm{i}$ company in $\mathrm{t}-1$ phase; $\triangle R E V_{i, t}$ is the main business income of $\mathrm{i}$ company in $\mathrm{t}$; $P P E_{i, t}$ is the total assets of $\mathrm{i}$ company in $\mathrm{t}$ phase. $\xi_{i, t}$ residuals for regression equation.

(3) Estimate the parameter of the model above, and then we obtain estimated value of industry parameter $a_{1} 、 a_{2}$ and $a_{3}$ then calculate the non-discretionary accrual profit of different profession listed companies by the following equation, that is $N D A_{i, t}$ :

$$
N D A_{i, t}=a_{1}\left(1 / A_{i, t-1}\right)+a_{2}\left(\Delta R E V_{i, t} / A_{i, t-1}-\Delta A R_{i, t} / A_{i, t-1}\right)+a_{3}\left(P P E_{i, t} / A_{i, t-1}\right)
$$

$N D A_{i, t}$ is non-discretionary accrual profit, $\triangle A R_{i, t}$ is the change of accounts receivable of $\mathrm{i}$ company in $\mathrm{t}$ phase.

(4) Calculate the discretionary accruals $D A_{i, t}$ According to the total accrual profit which is equal to manipulation of accruals and non-manipulation of accruals: $T A_{i, t} / A_{i, t-1}=N D A_{i, t}+D A_{i, t}$,

We can draw that:

$$
D A_{i, t}=T A_{i, t} / A_{i, t-1}-N D A_{i, t}
$$

$D A_{i, t}$ is manipulation of accruals.

\subsubsection{Independent variables and their measurements}

There are 6 independent variables in this paper, namely, the level of equity incentive (Marked as INCENTIVE), the overall executive power (Marked as POWER), the power of organization structure (Marked as POWER1), the expert power (Marked as POWER2), the Prestige power (Marked as POWER3), and the Ownership power (Marked as POWER4).Executive means the chairman or general Executive of the actual participation in the operation of the enterprise.

Executive equity incentive level is measured with the proportion of the total remuneration of the Executive options and options. This paper is based on the method proposed by Bergstresser and Philippon (2006) to measure the level of equity incentive through the following formula to calculate the Executive of equity and option compensation ratio:

$$
\text { INCENTIVES }_{i, t}=\frac{0.01 \times \text { PRICE }_{i, t} \times\left(\text { CSHARES }_{i, t}+\text { OPTIONS }_{i, t}\right)}{0.01 \times \text { PRICE }_{i, t} \times\left(\text { CSHARES }_{i, t}+\text { OPTIONS }_{i, t}\right)+\text { CASHPAY }_{i, t}}
$$


INCENTIVES said the total compensation rate of equity option, PRICE $_{i, t}$ for the closing price of the company's I shares at t. CSHARES $_{i, t}$ and $\operatorname{OPTIONS}_{i, t}$, they are respectively the number of shares and options held by $\mathrm{T}$ company executives, CASHPAY $_{i, t}$ for the year's cash salary, including annual salary and all kinds of allowances.

The Executive's overall power (POWER) is obtained by means of an average of four power in arithmetic. Organization structure power (POWER1) is measured with the position of CEO and chairman. If the two positions are held by the same people, it will be valued of 2.If the chairman is the highest Executive assignment, it will be valued 1, and it is valued 0 in other situation. Expert power (power2) is measured with the Executives' last qualification, the years of working in the field and the years being high management position in arithmetic average. Junior college degree or below is represented by 0 , Junior college and bachelor's degree being represented by 1 , graduate and above being represented by 2 ; the years of working in the field and the years being high management position, 0 was marked if the number of years is smaller than five years, 1 beijing marked from 5 to 15 years, and 2 being marked 15 years and above. Prestige power (power3) refers to reputation of the Executives in the industry, which is named commendatory, derogatory and neutral. The commendatory is marked with 2 , neutral is marked with 1 , and the derogatory is marked with 0 . The judgement of value is obtained through the Baidu search Executive reviews.

\subsubsection{Control variables and their measurements}

Some scholars have found that the size of the company (An \& Wang, 2007) and asset liability ratio (Geng, Zhang \& Fan, 2012) will also affect earnings management. It provides more opportunities and more space for Executive to make earnings management. Because the company has greater size, there will be more business and greater number of operating profit. The higher the rate of asset Liability of Company, the more likely the company make earnings management. Measurement of each variable is shown in table 1: 
Table 1. variable definition and explanation

\begin{tabular}{|c|c|c|c|}
\hline $\begin{array}{l}\text { Variabl } \\
\text { e type }\end{array}$ & Symbol & Variable name & Variable description \\
\hline $\begin{array}{l}\text { Depend } \\
\text { ent } \\
\text { variabl } \\
\text { e }\end{array}$ & $|\mathrm{DA}|$ & $\begin{array}{l}\text { Extent of earnings } \\
\text { management }\end{array}$ & $\begin{array}{l}\text { Discretionary accruals based on modified cross-sectional } \\
\text { Jones model }\end{array}$ \\
\hline \multirow[t]{5}{*}{$\begin{array}{l}\text { Indepe } \\
\text { ndent } \\
\text { variabl } \\
\text { e }\end{array}$} & $\begin{array}{l}\text { INCENTIVE } \\
\text { POWER }\end{array}$ & $\begin{array}{l}\text { Extent of equity } \\
\text { incentives } \\
\text { executive power }\end{array}$ & $\begin{array}{l}\text { The ratio of Executives' equity and options to total } \\
\text { compensation } \\
\text { The overall power of the Executive, the arithmetic average } \\
\text { of the four dimensions of power }\end{array}$ \\
\hline & POWER1 & $\begin{array}{l}\text { Organization } \\
\text { structure power }\end{array}$ & Whether serves as the chairman of the board \\
\hline & POWER2 & Expert power & $\begin{array}{l}\text { Education, the current number of years of working in the } \\
\text { field and being Executive }\end{array}$ \\
\hline & POWER3 & Prestige power & $\begin{array}{l}\text { Reputation in the industry, commendatory, derogatory and } \\
\text { neutral points }\end{array}$ \\
\hline & POWER4 & Ownership power & Whether is or not the company's major shareholders \\
\hline \multirow{2}{*}{$\begin{array}{l}\text { control } \\
\text { variabl } \\
\text { e }\end{array}$} & SIZE & Company size & Natural logarithm of total assets \\
\hline & DEBT & $\begin{array}{l}\text { Asset-liability } \\
\text { ratio }\end{array}$ & Liabilities divided by total assets ratio \\
\hline
\end{tabular}

\section{Analysis of study}

\subsection{Correlation Analysis}

This paper uses SPSS22.0 for data analysis. Firstly, variable correlation is analyzed, and outcome is showed in table 2. From table 2, we can find correlation coefficient between Executive power (POWER) and $|\mathrm{DA}|$ is 0.054 , correlation is not significant; correlation coefficient between POWER 1 and $|\mathrm{DA}|$ is -0.10 , and the correlation is not significant too; correlation coefficient between POWER 2 and $|\mathrm{DA}|$ is $0.404, \mathrm{p}<0.05$, which show that POWER2 is significant positive to earning management; correlation coefficient between POWER3 and $|\mathrm{DA}|$ is $-0.156, \mathrm{p}<0.05$, which show POWER3 is significant negative to earning management; correlation coefficient between POWER4 and $|\mathrm{DA}|$ is -0.029 , correlation is not significant. In the aspect of control variables, the size of the company, asset liability ratio and earnings management are significantly positive relate to earning management. 
Table 2. Variable correlation coefficient matrix

\begin{tabular}{|c|c|c|c|c|c|c|c|c|}
\hline & $|\mathrm{DA}|$ & INCENTIVE & POWER & POWER1 & POWER2 & 2 POWER3 & POWER4 & 4 Scalc \\
\hline INCENTIVE & .037 & & & & & & & \\
\hline POWER & .054 & $.388^{* *}$ & & & & & & \\
\hline POWER1 & -.010 & $.498^{* *}$ & $.789^{* *}$ & & & & & \\
\hline POWER2 & $.404^{* *}$ & -.084 & .110 & -.048 & & & & \\
\hline POWER3 & $-.301^{* *}$ & .040 & $.287^{* *}$ & $.169^{*}$ & $-.203^{* *}$ & & & \\
\hline POWER4 & -.029 & $.606^{* *}$ & $.686^{* *}$ & $.687^{* *}$ & -.119 & .099 & & \\
\hline Scale & $.199^{* *}$ & $-.296^{* *}$ & -.129 & $-.193^{* *}$ & $.267^{* *}$ & -.047 & $-.326^{* *}$ & \\
\hline Debt & $.267^{* *}$ & $-.320^{* *}$ & $-.159^{*}$ & $-.189^{* *}$ & $.234^{* *}$ & -.076 & $-.279^{* *}$ & $.700^{* *}$ \\
\hline
\end{tabular}

Note: ${ }^{* * *}$ means $\mathrm{p}<0.01 ; * *$ indicates $\mathrm{p}<0.05{ }^{*}$ means $\mathrm{p}<0.1$

\subsection{The effect of Executive power on earning management}

\subsubsection{The effect of the whole Executive power on the earnings management}

In model1, the independent variable is incentive, and the dependent variable is earning management. In model2, the independent variable is equity incentive, the mediate variable is management whole power, and the dependent power is earning management. In above two models, the control variables are the size of company and the financial leverage. Statistical analysis results are shown in table 3.

Table 3. the influence of the overall power of Executives on the earnings management

\begin{tabular}{lll}
\hline & Model 1: Incentive & Model 2: whole power \\
\hline Size & 1.737 & 2.2614 \\
Debt & $7.230^{* *}$ & $7.386^{* *}$ \\
Whole Power & & -0.844 \\
Incentive & $1.848^{*}$ & -2.542 \\
Whole Power $\times$ incentive & & 2.176 \\
$\mathrm{R}^{2}$ & 0.087 & 0.114 \\
$\Delta \mathrm{R}^{2}$ & 0.016 & 0.027 \\
ajd. $\mathrm{R}^{2}$ & 0.074 & 0.093 \\
$\mathrm{~F}$ & 6.756 & 5.391 \\
\hline
\end{tabular}

Note: $* * *$ means $\mathrm{p}<0.001$; ** means $\mathrm{p}<0.01$; $*$ means $\mathrm{p}<0.05$

From model 1, it can be found that equity incentive has a significant positive impact on earnings management (coefficient is $1.848, \mathrm{P}<0.05$ ). In model 2, the role of the Executive's overall power is not significant relate to earnings management $(\mathrm{P}>0.1)$, which shows the management whole power cannot significantly increase or reduce the impact of equity incentive on earnings management. 


\subsection{The effect of four kind of different Executive powers on the earnings management}

This part separately carries on regression analysis with the four different powers of Executive. The results of the analysis are shown in Table 4.

Table 4. the influence of different Executives' power on earnings management

\begin{tabular}{|c|c|c|c|c|}
\hline & Model3:Power1 & Model 4:Power2 & Model 5:Power3 & Model6:Power4 \\
\hline Size & 1.844 & -1.144 & 1.916 & 1.787 \\
\hline Debt & $7.223^{* *}$ & $6.554^{* *}$ & $6.606^{* *}$ & $6.699^{* *}$ \\
\hline Incentive & 0.137 & 0.297 & $3.031^{*}$ & -0.352 \\
\hline Power1 & $-3.116^{*}$ & & & \\
\hline Power $1 \times$ incentive & $4.872^{*}$ & & & \\
\hline Power2 & & $2.603^{* *}$ & & \\
\hline Power $2 \times$ incentive & & 1.713 & & \\
\hline Power3 & & & $-1.943^{*}$ & \\
\hline Power $3 \times$ incentive & & & -1.098 & \\
\hline Power4 & & & & $-3.435^{*}$ \\
\hline Power $4 \times$ incentive & & & & $5.475^{*}$ \\
\hline $\mathrm{R}^{2}$ & 0.106 & 0.217 & 0.151 & 0.106 \\
\hline$\Delta \mathrm{R}^{2}$ & 0.033 & 0.145 & 0.078 & 0.033 \\
\hline ajd. $R^{2}$ & 0.084 & 0.199 & 0.171 & 0.085 \\
\hline $\mathrm{F}$ & 4.963 & 11.674 & 8.653 & 4.984 \\
\hline
\end{tabular}

Note: ${ }^{* * *}$ means $\mathrm{p}<0.001 ; * *$ means $\mathrm{p}<0.01 ; *$ means $\mathrm{p}<0.05$

(1) In model 3, the Executive organizational structure power has a negative impact on earnings management (coefficient is $-3.116, \mathrm{p}<0.05$ ). However, the equity incentive and Executive power of the common role of earnings management have a positive impact on it (coefficient is $4.872, \mathrm{P}<0.05$ ). This proves hypothesis 1 and shows that when Executives have equity incentive, and Executives have greater motivation to earnings management, they can make use of the high organizational structure power to provide convenience to make earnings management.

(2) In model 4, the Executive expert power has a positive impact on earnings management (coefficient is $2.603, \mathrm{P}<0.05$ ), which partially supports hypothesis 2 . This shows that it is more convenient to conduct earnings management with good experience. While the Executive with expert power has the equity incentive plan, the earnings management motivation is stronger.

(3) In model 5, Executive reputation power negatively affects earnings management (coefficient is $-1.943, \mathrm{P}<0.05$ ). When equity incentive and Executives' reputation power work together, it still has a negative impact on earnings management (coefficient is $-1.098, \mathrm{P}<0.05$ ). The results show that hypothesis 3 is supported, which indicates that the Executive's 
reputation power is very important. They would not like to make earning management in order to get high reward by equity incentive. That is to say, "face" may be more important than money.

(4) In Model 6, Executive Ownership power has a negative impact on earnings management (coefficient is $-3.453, \mathrm{P}<0.05$ ). The impact of the power changes the direction of earnings management and will have a positive impact when management's control power and equity incentive make effects at the same time. The results show that the hypothesis 4 is testable, and the reason is that when Executives' equity can be sold in stock markets, and the motivation to obtain excess returns is greater than to avoid earnings management.

(5) The statistical results of the four models show that the four different Executive power has different influence in direction and in degree on earnings management, which may lead to the impact of the overall power of Executive on earnings management is uncertain.

\section{Management inspiration}

Although equity incentive can reduce agency costs and improve corporate performance, it may also stimulate the Executives' earnings management behavior. In the absence of equity incentive, Executives' reputation and the owners' rights have a tendency to reduce the Executives' earnings management. However, earnings management may bring excess returns to equity holders, resulting in the Executive to make earnings management. Government and the enterprises need formulate relating measures according to the function mechanism of each power to reduce the earnings management of the enterprise.

\subsection{Organizing relevant training to improve the Executive of the entrepreneur spirit}

When the Executives' equity can be sold through securities market, the higher the stock price, the more revenue they can get. Executives with high organizational structure or ownership power have the advantage of manipulating earnings to improve the book performance. Entrepreneurs being not saints, they will choose to sell their stocks to get cash by the temptation of the capital market or when they losing the driving force to make continuous efforts for the company's development. Government should regularly organize relevant training to improve their entrepreneurial spirit. As Executives of strong entrepreneurial spirit, their thoughts and motivation are often concentrated on how to improve or maintain the competitive advantage of the enterprise, rather than study how to make good financial statements.

\subsection{Increase the intensity of information disclosure, and strengthen the implementation of punishing on violations of information}

Executive expert power provides business technical support for management surplus. However, no matter how strong the ability of business is, the more detailed disclosure of financial information is, the greater the possibility of leakage will be. To improve the 
financial information disclosure requirements of enterprises, Executives will tend to reduce the motivation of earnings management. At present, one of the reasons for the release of illegal information is that the punishment is very light and there is no substantive punishment. On the contrary, if severe punishment measures toward illegal release information can be effectively implemented, it will greatly enhance the risk of earnings management, thus reducing the willingness of its earnings management.

\subsection{Employ highly prestigious Executives}

Firstly, high reputation Executives have two characteristics: outstanding performance and good entrepreneurial spirit. These characteristics make them devote themselves to the substantive development of the enterprise, and reduce the motivation of the enterprise to gloss over the financial report through earnings management. Secondly, due to the high reputation, Executives have a strong spiritual appeal to the management team, to build corporate culture and train team spirit of hard work. In addition to, as the high reputation Executives, they are not willing to make improper actions to destroy their own reputation.

\section{Funding}

The research received support from the fundamental research funds for the central universities of Nanjing University of Aeronautics and Astronautics (Grant number NS2015082), the National Natural Science foundation of China (Grant number 71473131; 71573123), the National Social science foundation of China(16BGL106,15BGL094).

\section{Reference:}

Achilles, W. W., Blaskovich J. and Pitre T J. (2013), "The Relationship Between Compensation, Motivation, And Earnings Management"[J]. Journal of Applied Business Research, vol.29, no.2, PP. 579-588.

Bantel, K.A. and Jackson,S. E. (1989) “Top Management and innovations in banking: Does the composition of the top team make a difference"[J]. Strategic Management Journal, no.3, pp.107-124.

Bebchuk, L. A. and Fried, J. M. (2003), "Executive compensation as an agency problem”[R]. National Bureau of Economic Research.

Chung, K. H. and Pruitt, S. W.(1996), "Executive ownership, corporate value, and executive compensation: A unifying Framework" [J]. Journal of Banking \& Finance, vol.20, no.7, pp. 1135-1159.

Crystal, G.(1991) “In search of excess”[M]. NewYork:Norton.

Ding Baoli, Wang Shenghai and Liu Xiyou(2012) "Research on the development direction of stock option incentive mechanism in China" [J]. Accounting Research, no.6, pp.76-80. 
Fama, E. (1980) "Agency problems and the theory of the firm"[J]. Journal of Political Economy, no.2, pp. 288-307.

Finkelstein, S. (1992), "Power in top management teams: Dimensions, measurement, and Validation" [J]. Academy of Management Journal, vol.35, no.3, pp.505-538.

Geng Jianxin, Zhang Chi and Liu Fengyuan (2012) "Venture capital can improve the efficiency of venture capital enterprise governance: A Perspective of earnings management" [J]. Economic Problems, no.9, pp.1-16.

Gomez-Mejia, L., Larraza-Kintana and M. and Makri, M. (2003), "The Determinants of Executive Compensation in Family Controlled Publicly Traded Corporations"[J] Academy of Management Journal, vol.44, no.2, pp. 226-237.

$\mathrm{Gu}$ Zhenwei, Qin Mo and Ouyang Lingnan (2008) "Improved extended Jones model and other measurement of earning management model comparison " $[\mathrm{J}]$. Financial Essays, no.5, pp.78-83.

Hambrick, D.C. and Finkelstein, S. (1987), "Managerial discretion: A bridge between polar views of organizational outcomes " $[\mathrm{J}]$. Research in Organizational Behavior, no.9, pp.369-406.

Harhoff D. (1999), "Innovation objectives, managerial education and firm performance-an exploratory analysis”[M] . New York: NY, Springer.

Huang Qunhui and Li Chunqi (2001), "The incentive of compensation, reputation and operator's long-term behavior '[J]. China Industrial Economy, no.1, pp.58-63.

Li Peigong and Shen Yi Feng (2013), "Compensation Manager, sensational report and the media's role in corporate governance". Journal of Management Sciences, no.10, pp.63-80.

Li Xiaohui and Li Bin Liang (2014) "Study on high-tech enterprise in R \& D expenditures are capitalized earnings management -- Based on the case of TYDIC company analysis" [J]. Accounting Friends, no.25, pp.58-63.

Li Zengfu, Dong Zhiqiang and Lian Yujun (2011), “Accrual earnings management or real activity earnings management -- Based on the research of China's income tax reform in 2007 '[J]. Management World, no.1, pp.121-134.

Lv Changjiang and Gong Na (2009), "Equity incentive analysis -- to Erie shares as an example "[J]. Accounting Research, no.5, pp.53-62.

Wang Kemin and Wang Zhichao (2007), "Executive control, compensation and earnings management: An Empirical Study Based on China's listing Corporation "[J]. Management World, no.7, pp. 47-56.

Wang Ying (2011), "Managerial power, compensation incentive and enterprise performance" [D]. Nanjing: Nanjing University of Finances and Economics. 
Wang Ying, Guan Jiancheng and Ma Ning (2003), "Study on the relationship between top management, innovation strategy and performance of Chinese enterprises" [J]. Journal of Management Engineering, no.1, pp. 1-7.

Xiao Feng Quan and Wu Shinong (2010), "CEO power, information disclosure quality and the performance of the company's Volatility -- Based on an empirical study of Shenzhen Stock Exchange listed companies ”[J]. Nankai Business Review, no.1, pp.142-153.

Xiao Shufang and Zhang Chenyu, Zhang Chao,Xuan Ran (2009), "Equity incentive plan is announced before the earnings management -- from the empirical evidence of Listed Companies in China "[J]. Nankai Business Review, vol.12, no.4, pp.113-119.

Zhang Liping and Yang Xingquan (2012), "Executive power, management incentive and over investment "[J]. Soft science, vol.26, no.10, pp.107-112.

Zhao Chunxiang and Luo Fei (2013), "Market competition, managerial power and pay stickiness "[J]. Contemporary Finance, no.10, pp.76-85.

Zhao Chunxiang and Zhang Dunli (2013), "Market competition from the perspective of Executive power and enterprise investment relationship" [J]. Accounting Research, no.10, pp.67-75. 